\title{
INOVASI PELAKSANAAN POSYANDU SELAMA MASA PANDEMI COVID-19: STUDI KUALITATIF DI WILAYAH KERJA PUSKESMAS CAMPALAGIAN
}

\author{
Najdah, Nurbaya ${ }^{\bowtie}$ \\ Jurusan Gizi Poltekkes Kemenkes Mamuju
}

\section{ARTICLE INFO \\ Article history}

Submitted : 2021-11-20

Revised : 2021-11-26

Accepted : 2021-11-29

\section{Keywords:}

Posyandu

Cadre

Pandemy

Covid-19

Stunting

Qualitative

\section{Kata Kunci:}

Posyandu

Kader

Pandemi

Covid-19

Stunting

Kualitatif

\section{ABSTRACT}

Posy andu cadres play an important role in assisting Public Health Center in carry ing out the functions of implementing health efforts and have a strategic position to prevent stunting problems, especially in time the Covid-19 pandemic. This study aimed to describe the implementation of Integrated Health Post (Posyandu) in the working area of the Campalagian Health Center during the Covid-19 pandemic in 2020. This study qualitative used a phenomenology approach which was carried out in the working area of the Campalagian Health Center in July - September 2020. A total of 10 Posyandu cadres were the main informants. Data were collected through in-depth interviews for 60 - 90 minutes conducted at the homes of Posy andu cadres while still pay ing attention to health protocols. Cadres did not carry out Posy andu in April and May 2020 following local government regulations or in certain months when there was an increase in cases of Covid-19 in the area. In implementing the Posyandu during the pandemic, cadres made several innovations such as setting up emergency handwashing facilities, arran ging visit schedules, and the distance of waiting chairs at the Posyandu, requiring them to bring their own sharoong from home for weighing toddlers and disinfecting the Posyandu room. In conclusion, cadres make innovations in the implementation of Posyandu during the pandemic such as preparing emergency hand washing facilities, arran ging visit schedules and waiting chair spacing at Posy andu, requiring them to bring their own gloves and disinfecting the Posy andu room. The implementation of Posy andu during the Covid-19 pandemic can prevent an increase in nutritional problems in mothers and stunting problems in toddlers. Therefore, the local government is expected to support the implementation of Posy andu routinely such as ensuring the availability of PPE for posyandu cadres, mothers and toddlers. So that Posyandu can still be implemented while still observing health protocols.

Kader Posy andu mempuny ai peran penting dalam membantu untuk menjalankan fungsifungsi Puskesmas sebagai penyelenggaraan upaya kesehatan serta memiliki fungsi strategis untuk mencegah terjadiny a masalah stunting terutama di masa pandemi Covid19. Penelitian ini bertujuan untuk mengetahui gambaran pelaksanaan Posyandu di wilayah kerja Puskesmas Campalagian selama masa pandemi Covid-19 tahun 2020. Penelitian kualitatif menggunakan pendekatan fenomenologi yang telah dilakukan di wilay ah kerja Puskesmas Campalagian pada bulan Juli - September 2020. Sebany ak 10 kader posyandu yang menjadi informan utama. Data dikumpulkan secara wawancara mendalam (in-depth interview) selama 60 - 90 menit yang dilakukan di rumah kader Posyandu dengan tetap menjalankan protokol kesehatan. Hasil penelitian menunjukkan bahwa kader tidak melaksanakan Posyandu pada bulan April dan Mei tahun 2020 sesuai dengan aturan pemerintah setempat atau pada bulan-bulan tertentu ketika terjadi peningkatan kasus positif Covid-19 di daerah tersebut. Dalam pelaksanaan Posy andu di masa pandemi, kader membuat beberapa inovasi seperti menyiapkan fasilitas cuci tangan darurat, mengatur jadwal kunjungan dan jarak kursi tunggu di Posyandu, mewajibkan membawa sarung sendiri dari rumah untuk kegiatan penimbangan balita serta melakukan disinfektan ruang Posyandu. Sebagai kesimpulan bahwa kader melakukan inovasi dalam pelaksanaan Posyandu di masa pandemi seperti menyiapkan fasilitas cuci tangan darurat, mengatur jadwal kunjungan dan jarak kursi tunggu di Posyandu, mewajibkan membawa sarung sendiri serta melakukan disinfektan ruang Posyandu. Pelaksanaan Posyandu di masa pandemi Covid-19 dapat mencegah terjadinya peningkatan masalah gizi pada ibu dan masalah stunting pada balita. Oleh karena itu, pemerintah darah diharapkan dapat mendukung pelaksanaan Posyandu secara rutin seperti menjamin ketersediaan APD bagi kader posyandu, ibu dan balitanya. Sehingga Posyandu tetap dapat dilaksanakan dengan tetap memperhatikan protokol kesehatan. 


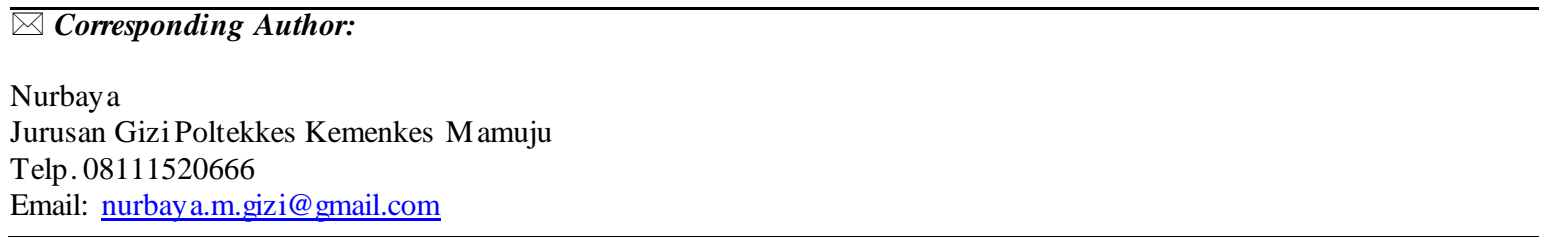

\section{PENDAHULUAN}

Posyandu (Pos Pelayanan Terpadu) merupakan upaya kesehatan masyarakat yang dise lenggarakan dari, oleh dan untuk masyarakat yang dibantu oleh petugas kesehatan (Kemenkes RI, 2012). Beberapa kegiatan vital yang dilakukan di Posyandu antara lain mengukur dan memantau status gizi dan kesehatan pada ibu dan balita, keluarga berencana, pelaksanaan imunisasi dan pencegahan dan penanggulangan diare (Arif, Isdijoso, Fatah, \& Tamyis, 2020). Sasaran Posyandu antara lain ibu (hamil, nifas, menyusui), bayi dan balita serta pasangan usia subur (Bidayati, 2017).

Kader Posyandu sifatnya dinamis mampu melaksanakan beberapa kegiatan yang sederhana tetapi tetap berguna bagi masyarakat kelompoknya. Keberadaan Posyandu sangat berperan penting dalam upaya peningkatan kesehatan masyarakat khususnya ibu dan balita. Sementara itu kader Posyandu adalah penyelenggara, penggerak dan promotor kegiatan Posyandu (Rinayati, Erawati, \& Wahyuning, 2020).

Kader sangat berperan penting dalam membantu Puskesmas dalam menjalankan fungsi-fungsi penyelenggaraan upaya kesehatan. Mereka bekerja secara suka rela untuk membantu upaya peningkatan kesehatan di masyarakat. Jika kegiatan Posyandu terlaksana dengan baik secara rutin maka dapat memberikan kontribusi yang besar dalam upaya pemantauan status gizi ibu dan balita sebagai bagian dari upaya pencegahan stunting pada balita dan peningkatan derajat kesehatan masyarakat di Indonesia (Sari, Chiani, \& Astuti, 2020).

Namun, pada 11 Maret 2020 pemerintah Indonesia menyatakan telah menemukan pasien kasus positif Covid-19 untuk pertama kalinya. Penyebaran Covid-19 terjadi sangat cepat di berbagai negara hingga akhirnya WHO menyatakan Covid-19 sebagai pandemi global (Nicola et al., 2020).

WHO merekomendasikan pembatasan gerak fisik dan sosial (physical and social distancing) sebagai salah satu upaya untuk mencegah penularan Covid-19 (Qian \& Jiang,
2020). Pembatasan jarak fisik membantu membatasi penyebaran Covid-19. Masyarakat dihimbau untuk menjaga jarak minimal 1-2 meter antar satu sama lain dan menghindari menghabiskan waktu di tempat ramai atau berkelompok (WHO, 2020).

Di Indonesia sendiri, pembatasan gerak sosial ini dikenal sebagai Pembatasan Sosial Berskala Besar (PSBB). Hal ini berdampak pada semua sektor kehidupan seperti sektor ekonomi, pendidikan, hingga dampak pada kesehatan itu sendiri, termasuk terganggunya pelayanan kesehatan hingga ke tingkat Pratama seperti Puskesmas dan Posyandu (World Food Programme, 2020). Kesulitan terbesar dalam pelayanan kesehatan banyak dialami oleh negara-negara berpenghasilan rendah dan menengah, termasuk Indonesia. Faktanya, kapasitas sistem kesehatan yang tidak memadai di negara-negara tersebut membuat mereka semakin rentan terhadap Covid-19 (Akseer, Kandru, Keats, \& Bhutta, 2020; Kemenkes RI, 2020b)

Kebijakan pembatasan gerak sosial menyebabkan terbatasnya bahkan tidak adanya pelayanan di Posyandu untuk menghindari kerumunan di Posyandu yang bisa menyebabkan tingginya potensi penularan virus corona. Terbatasnya pelayanan di Posyandu berdampak pada pelayanan Kesehatan ibu dan balita serta terhambatnya pemantauan tumbuh kembang balita (Kemenkes RI, 2020a). Oleh karena itu, penelitian ini dilakukan untuk mengetahui gambaran pelaksanaan Posyandu di wilayah kerja Puskesmas Campalagian selama masa pandemi Covid-19 tahun 2020.

\section{METODE PENELITIAN}

\section{Jenis Penelitian}

Penelitian ini adalah penelitian kualitatif yang menggunakan pendekatan fenomenologi. Pendekatan fenomenologi dalam penelitian kualitatif berusaha merangkum fenomena tentang apa yang dialami, perilaku, persepsi, tidankan dan motivasi subyek penelitian (Creswell \& Poth, 2018).

\section{Lokasi dan Waktu Pene litian}


Penelitian ini dilakukan di wilayah kerja Puskesmas Campalagian pada bulan JuliSeptember 2020. Puskesmas Campalagian terletak di Kecamatan Campalagian, Kabupaten Polewali Mandar, Sulawesi Barat.

\section{Pengumpulan Data}

Wawancara mendalam (in-depth interview) dilakukan untuk menggali informasi tentang pelayanan Posyandu selama masa pandemi Covid-19 sejak Maret hingga Agustus 2020. Durasi wawancara mendalam antara 6090 menit dan dilakukan di rumah kader Posyandu dengan tetap memperhatikan protokol kesehatan. Adapun informan utama dalam penelitian ini adalah kader Posyandu yang berasal di 3 Posyandu.

Sebanyak 10 kader Posyandu yang bekerja di wilayah Kerja Puskesmas Campalagian bersedia secara suka rela terlibat dalam penelitian. Kami pun melakukan triangulasi dengan mewawancarai bidan dan petugas gizi yang bertugas di daerah tersebut. Semua wawancara dilakukan dalam bahasa Indonesia.

Semua kegiatan wawancara direkam menggunakan alat perekam suara. Rekaman hasil wawancara lalu ditranskrip verbatim pada fail Ms. Word. Peneliti melakukan pengecekan berulang pada rekaman dan hasil transkrip untuk memastikan kelengkapan informasi. Tahap selanjutnya adalah tahap analisis data.

\section{Pengolahan dan Analis is Data}

Hasil transkrip tersebut lalu dianalisis melalui tiga tahap yaitu, pengkodean dan reduksi data (coding), pengelompokan data (categorizing) dan penarikan kesimpulan. Proses pengkodean dan reduksi data adalah tahap dimana peneliti memilih dan melakukan pengkodean data serta menyederhanakan data sesuai tujuan penelitian yang telah ditetapkan (Creswell \& Poth, 2018).

Setelah pengkodean data (coding), tahap selanjutnya adalah pengelompokan data berdasarkan tema yang muncul lalu dilakukan penarikan kesimpulan sebagai hasil dari penelitian ini. Adapun data yang telah diolah akan ditampilkan dalam bentuk narasi dan kutipan dari informan dengan tetap menjaga kerahasiaan data informan.

Peneliti juga melakukan triangulasi dengan mewawancarai bidan desa dan Tenaga Pelaksana Gizi (TPG) yang terlibat pada pelaksanaan Posyandu. Kegiatan triangulasi ini dilakukan untuk meningkatkan validitas data yang telah dikumpulkan (Creswell \& Poth, 2018).

\section{HASIL PENELITIAN}

Berdasarkan analisis data hasil wawancara diperoleh tiga tema utama, yaitu:

a. Gambaran pelayanan Posyandu pada masa pandemi Covid-19.

b. Gambaran inovasi pelaksanaan Posyandu pada masa pandemi Covid-19.

c. Gambaran kunjungan rumah (Home visit).

\section{Pelayanan Posyandu pada Masa Pandemi Covid-19}

Informan diwawancarai tentang pelaksanaan Posyandu selama masa-masa awal pandemi merebak di Indonesia yaitu sejak bulan Maret hingga September 2020. Berdasarkan informasi yang disampaikan oleh informan, semua informan menjawab bahwa pelayanan Posyandu di wilayah kerja mereka sempat terhenti selama dua hingga tiga kali namun pada bulan yang berbeda. Sebagian besar informan menjawab bahwa kegiatan di Posyandu tidak dilaksanakan pada awal maraknya Covid-19 di Indonesia yaitu pada bulan April dan Mei tahun 2020.

"Kami dapat informasi dari petugas kesehatan di sini bahwa kami tidak boleh melaksanakan Posyandu dulu. Waktu itu seingat saya bulan empat dan lima. Waktu awal masuk Covid-19 bulan Maret, masih sempat dilaksanakan." (Informan 1)

"Sekitar bulan 4 dan 5 yang lalu kami benar-benar tidak ada kegiatan Posyandu. Karena ada kebijakan dari kepala desa tidak boleh ada aktivitas berkerumun. Termasuk kegiatan Posyandu, karena pasti berkumpul dan berdekatan semua." (Informan 8)

Informan menjelaskan bahwa setelah bulan Mei tahun 2020 ada kebijakan dari aparat desa dan Puskesmas setempat untuk melaksanakan Posyandu secara terbatas. Setelah itu kegiatan Posyandu terlaksana lagi dengan mematuhi protokol kesehatan. 
"Bulan enam kami melaksanakan Posyandu. Tapi terbatas dan tidak boleh berkempul banyak-banyak." (Informan 5).

ok"Saya ingat cuma dua bulan kami tidak melakukan Posyandu. Setelah itu bulan 6 baru ada posyandu. Tapi kalau tidak salah hanya dua bulan saja. Terus lockdown lagi." (Informan 3)

Meskipun Posyandu dapat dilaksanakan bulan Juni tahun 2020, namun pada bulan-bulan tertentu, pelaksanaan Posyandu dihentikan sesuai dengan peningkatan jumlah kasus Covid19 di wilayah kerja Puskesmas Campalagian. Beberapa informan menjelaskan bahwa kegiatan Posyandu sempat terhambat lagi pada bulan Juli dan Agustus karena adanya peningkatan kasus Covid-19 di desa wilayah kerja Posyandu tersebut.

"Kami buka Posyandu itu hanya dua bulan saja. Tapi pas ada lagi kluster pesantren jadi Posyandu tidak dilaksanakan lagi. Khawatir juga jangan sampai banyak menularkan corona." (Informan 4)

"Seingat saya, kita melakukan Posyandu itu sekitar bulan 6 dan 7. Tapi terbatas saja, tidak seperti waktu sebelum Covid19" (Informan 5)

Dari penjelasan yang disampaikan oleh informan bahwa pelayanan Posyandu kadang tidak dilaksanakan sesuai dengan peningkatan jumlah kasus positif Covid-19 di daerah tersebut dan berdasarkan kebijakan aparat desa.

"Kalau tidak salah bulan delapan (Agustus) kita tidak Posyandu karena Puskesmas juga tutup. Waktu itu banyak kasus positif. Tidak ada Posyandu lagi." (Informan 9)

\section{Inovasi Pelaksanaan Posyandu pada Masa Pandemi Covid-19}

Berdasarkan penjelasan dari informan bahwa para kader Posyandu telah berupaya menerapkan standar protokol kesehatan pencegahan Covid-19 dalam setiap pelaksanaan Posyandu. Petugas kesehatan dan kader
Posyandu berusaha secara mandiri menerapkan protokol kesehatan dengan menyiapkan fasilitas cuci tangan, sabun cuci tangan, hand sanitizer, mengatur jadwal kunjungan ke Posyandu, dan mengatur jarak kursi tunggu bagi ibu balita.

Berikut beberapa inovasi yang diinisiasi oleh kader Posyandu dalam rangka pencegahan penularan Covid-19 di Posyandu:

a. Menyiapkan fasilitas cuci tangan dan hand sanitizer

b. Mewajibkan pakai masker bagi semua pengunjung Posyandu

c. Mengatur jadwal kunjungan dan jarak kursi tunggu di Posyandu

d. Wajib membawa sarung sendiri dari rumah

e. Melakukan disinfektan ruang Posyandu

\section{Menyiapkan fasilitas cuci tangan dan hand sanitizer}

Para informan menjelaskan bahwa selama masa pandemi, mereka menyiapkan tempat cuci tangan darurat yang ditujukan untuk setiap pengunjung Posyandu. Jadi setiap pengunjung wajib mencuci tangan dan menggunakan hand sanitizer.

"Pas corona kan kita tutup dua bulan, nah pas buka lagi Posyandu, kami siapkan sendiri tempat cuci tangan dan sabunnya. Tapi begitulah, masih terbatas." (Informan 1)

"Aslinya Posyandu kan memang tidak ada tempat cuci tangan. Jadi selama corona ini, kita siapkan sendiri. Kita kasi hand sanitizer juga." (Informan 10)

Tempat cuci tangan yang disiapkan adalah tempat cuci tangan darurat dan sifatnya non-permanen. Bentuknya berupa galon air isi ulang yang diletakkan di sekitar pintu atau jalur masuk Posyandu. Sayangnya karena belum memenuhi syarat tempat cuci tangan yang terstandar karena pembuangan airnya masih di ruang terbuka dan tidak dialirkan langsung ke saluran pembuangan.

"Iya kita buatkan tempat cuci tangan sementara. Pakai galon isi ulang yang dibagikan desa. Ada juga sabun cuci tangan." (Informan 1)

"Waktu pertama kan Posyandu-nya dilaksanakan di dekat rumah orang tua 
saya. Jadi kami buatkan tempat cuci tangan, kita sambung selang dari rumah orang tua saya. Jadi bisa dipakai untuk cuci tangan" (Informan 3)

Para kader berinisiatif menyiapkan tepat cuci dan sabun cuci tangan sehingga ibu balita yang datang dapat mencuci tangan. Mereka pun menyiapkan hand sanitizer, meskipun jumlahnya sangat terbatas. Hal ini mereka lakukan agar dapat melaksanakan kegiatan Posyandu dengan tetap meminimalisir penyebaran dan penularan virus corona.

\section{Ibu dan Anak Wajib Pakai Masker}

Salah satu protokol kesehatan pencegahan penularan Covid-19 adalah penggunaan masker. Semua informan menjelaskan bahwa selama masa pandemi Covid-19, semua ibu dan balita yang datang ke Posyandu wajib menggunakan masker.

"Kita wajibkan juga ibu dan balita yang datang harus pakai masker. Kasian anaknya tidak biasa pakai masker jadi biasa dilepas. Tapi kalau ke Posyandu balita juga tetap pakai masker." (Informan 5)

"Ibu dan anaknya harus pakai masker kalau ke Posyandu. Kita juga diwajibkan pakai masker." (Informan 1)

Berdasarkan hasil wawancara diperoleh bahwa para kader mewajibkan semua ibu dan balita yang datang ke Posyandu harus mematuhi protokol kesehatan termasuk dalam hal menggunakan masker. Kader dan petugas kesehatan yang hadir pada kegiatan Posyandu pun menggunakan masker sebagaimana dijelaskan oleh salah satu informan berikut.

"Kita semua kader wajib pakai masker. Begitu juga ibu-ibunya. Kita wajibkan seтua pakai masker. Anaknya juga disuruh pakai masker. Jadi, kadang anaknya pakai masker dewasa karena tidak punya masker anak-anak." (Informan 6)

\section{Mengatur Jadwal Kunjungan dan Jarak Kursi Tunggu di Posyandu}

Salah satu tantangan dalam pelaksanaan Posyandu di masa pandemi Covid-19 adalah menjaga jarak fisik dan tidak boleh berkerumun. Sementara kondisi Posyandu selama ini selalu dipadati oleh ibu-ibu dan balitanya. Sehingga untuk mengatasi tantangan tersebut, para kader berinisiatif untuk mengatur jadwal kunjungan sehingga ibu balita tidak datang bersamaan.

"Sekitar bulan 6 kami bisa melaksanakan Posyandu lagi. Tapi terbatas. Jadi kami membagi waktu kedatangan ibu dan balitanya. Ada yang datang jam 8, ada juga jam 10. Supaya tidak datang bersamaan semua." (Informan 2)

"Kita bagi waktu kunjungan. Jadi kita umumkan di masjid soal pembagian waktunya supaya ibu-ibunya tidak datang bersamaan. Tapi banyak juga ibu-ibu yang takut ke Posyandu." (Informan 10)

Selain itu, kader juga mengatur jarak kursi di ruang tunggu. Kader selalu menyampaikan kepada para ibu yang hadir di Posyandu untuk selalu menjaga jarak meskipun berada di ruang terbuka.

"Kami coba atur kursinya di Posyandu. Supaya tetap jaga jarak. Tapi di Posyandu, kadang ibu-ibunya tetap berkerumun. Tapi kami selalu mengingatkan ibu-ibunya supaya tetap jagajarak." (Informan 5)

"Posyandu kami ruangannya terbatas. Jadi ada yang duduk di luar, ada yang menunggu panas-panasan di luar. Kasian juga, tapi kita harus jaga jarak tempat duduknya." (Informan 3)

\section{Wajib Membawa Sarung Sendiri dari Rumah}

Kader Posyandu juga mewajibkan para ibu untuk membawa sarungnya sendiri sehingga sarung yang digunakan untuk menimbang adalah sarung sendiri. Aturan ini hanya diwajibkan bagi ibu yang mempunyai anak di bawah usia dua tahun yang pengukuran berat badannya menggunakan dacin dan sarung timbangan. Aturan ini dilakukan untuk 
mencegah penularan Covid-19 melalui sarung timbangan yang dipakai bersama.

"Kami mewajibkan ibu balita bawa sarungnya sendiri. Supaya lebih aman. Dulunya pakai sarung timbangan yang ada di sini. Selama pandemi akhirnya kita suruh ibunya bawa sendiri sarungnya dari rumah." (Informan 10)

Beberapa informan menyatakan bahwa mereka tidak melayani ibu balita yang tidak membawa sarung sendiri. Mereka meminta ibu balita untuk kembali untuk membawa sarung agar anaknya dapat ditimbang.

"Kalau ada ibu balita yang tidak bawa sarung, kami suruh pulang dulu ambil sarungnya. Karena sudah diumumkan satu hari sebelumnya wajib bawa sarung kalau penimbangan." (Informan 7)

Sedangkan bagi ibu yang mempunyai anak balita tidak diwajibkan membawa sarung karena penimbangan balita tidak menggunakan dacin, melainkan timbangan injak. Meski demikian, kader secara rutin melakukan disinfektan pada permukaan timbangan injak tersebut untuk menghindari penularan virus corona.

"Jadi lebih cape sebenarnya. Karena kita harus semprot dan lap terus itu timbangan. Dulu kan langsung naik, timbang” (Informan 4)

"Selama pandemi, setiap kali ada yang sudah ditimbang, kita bersihkan lagi timbangannya. Kalau yang dacin kan tinggal ganti sarung saja. Dulunya, tidak pernah dibersihkan ini timbangan. Sarungnya juga cuma pakai satu saja." (Informan 6)

Hal ini dibenarkan oleh salah satu bidan desa yang bertugas di wilayah kerja Puskesmas Campalagian. Informan tersebut menjelaskan bahwa selama masa pandemi Covid-19, semua kader diwajibkan untuk menerapkan protokol kesehatan seperti rutin mencuci tangan, penggunaan hand sanitizer, masker dan menjaga jarak.
"Selama masa pandemi ini, semua diwajibkan pakai masker, cuci tangan, dan jaga jarak. Bidan, petugas Kesehatan, kader dan ibu yang datang di Posyandu harus mematuhi protokol kesehatan. Balita yang dayang juga harus pakai masker." (Bidan A)

"Kita semua kader di sini wajib pakai masker. Hanya petugas Kesehatan dari Puskesmas yang pakai APD lengkap. Pakaian sepertijas hujan itu." (informan 4)

\section{Melakukan Disinfektan Ruang Posyandu}

Beberapa informan menyatakan bahwa mereka bekerja sama dengan aparat desa untuk melakukan disinfektan ruang Posyandu yang mereka gunakan. Kegiatan disinfektan ini dilakukan sehari sebelum hari posyandu.

"Kita minta tolong ke petugas desa supaya Posyandu kami di-disinfektan juga kalau mereka sedang keliling desa melakukan disinfektan." (informan 7)

Namun beberapa informan menyatakan bahwa mereka tidak melakukan disinfektan karena Posyandu mereka di bawah kolong rumah warga, jadi masih terhitung ruang terbuka. Ada juga yang beralasan bahwa mereka kurang tahu soal kebijakan disinfektan untuk Posyandu.

"Seingat saya tidak pernah dikasi disinfektan. Mungkin karena ruang terbuka. Dan Posyandu dilakukan hanya sekali. Beda seperti masjid dan pasar, ramai setiap hari." (informan 3 )

"Posyandu kami tidak disinfektan. Mungk in karena di ruang terbuka. Tapi kami bersihkan sebehum hari Posyandu." (informan 10)

\section{Kunjungan Rumah (Home Visit)}

Meskipun pemerintah setempat mengeluarkan kebijakan untuk menghentikan sementara pelayanan Posyandu, namun beberapa kader berinisiatif untuk tetap melakukan pemantauan tumbuh kembang balita melalui home visit atau kunjungan rumah. Home visit juga dilakukan untuk melakukan imunisasi terutama pada balita target imunisasi. 
"Kami akhirnya melakukan kunjungan ke rumah-rumah balita, namun khusus untuk balita yang BGM. Kasian kalau tidak dipantau pertubuhannya. Jangan sampai status gizinya makin buruk"(Informan 4)

"Kalau saya akhirnya setiap sore kadang kunjungan ke rumah balita, terutama yang kurus-kurus. Supaya kita bisa tetap pantau status gizinya. Kalau lockdown terus seperti bisa-bisa tidak ada laporan pemantauan status gizi." (Informan 2)

Selain itu, informan menyatakan bahwa mereka melakukan home visit bersama-sama dengan petugas kesehatan hanya pada keluarga yang memiliki balita yang belum lengkap imunisasinya. Dalam melaksanakan home visit, mereka tetap menggunakan APD dan mematuhi protokol kesehatan.

"Kalau saya, karena bertugas juga untuk imunisasi akhirnya kami hanya melakukan kunjungan rumah untuk imunisasi balita yang belum lengkap imunisasinya. Kita kunjungi satu per satu. Tapi susah kalau sekaligus menimbang. Masyarakat juga." (Informan 10)

"Kami datangi rumahnya satu-satu pakai APD lengkap. Tapi hanya untuk imunisasi saja. Susah kalau sekalian timbang. Karena imunisasi yang mendesak." (Informan 8)

Namun ada juga kader yang berinisiatif untuk menjadikan rumahnya sebagai Posyandu sementara namun tetap membatasi jumlah kunjungan sasaran setiap harinya. Ibu balita datang satu per satu ke rumah kader untuk melakukan penimbangan dan pengukuran tinggi badan.

"Waktu itu kalau tidak salah bulan 5, kami belum dapat ijin untuk melakukan Posyandu, tapi saya membuka rumah saya jika ada ibu balita yang ingin menimbang dan mengukur anaknya. Kasihan juga kalau tidak dipantau. Tapi saya sediakan sabun cuci tangan dan harus pakai masker di rumah."(Informan 5)

\section{PEMBAHASAN}

Posyandu menjadi kontak pertama pelayanan kesehatan bagi ibu hamil dan ibu balita untuk memantau perkembangan kehamilannya atau tumbuh kembang balitanya (Arif et al., 2020). Posyandu memiliki posisi strategis untuk mencegah terjadinya masalah stunting di masyarakat, termasuk deteksi dini faktor-faktor risiko stunting yang paling penting, seperti pola asupan gizi ibu dan anak, pola asuh, higiene dan sanitasi, dan masih faktor lainnya (Rahmawati \& Dewi Sartika, 2020).

Pelayanan kesehatan di tingkat primer menjadi berubah dan mengganggu pelayanan rutin bagi ibu dan balita selama masa pandemi. Sehingga berakibat pada risiko masalah gizi pada ibu dan risiko stunting pada balita semakin meningkat (Akseer et al., 2020). Kondisi ini menjadikan Posyandu menjadi pos pelayanan kesehatan yang cukup penting di masa pandemi.

Selama masa pandemi Covid-19, kader menyelenggarakan Posyandu sesuai dengan aturan pemerintah daerah dengan tetap mematuhi aturan pemerintah desa dan menjaga protokol kesehatan pencegahan Covid-19. Selain itu, pelaksanaan Posyandu juga dilaksanakan sesuai peningkatan kasus Covid19 di wilayah kerja Puskesmas Campalagian.

Berdasarkan hasil penelitian ini, bahwa kegiatan Posyandu tidak dilaksanakan pada bulan April-Mei tahun 2020 atau pada bulan tertentu ketika terjadi peningkatan kasus positif Covid-19 di bulan tersebut. Hal ini sejalan dengan kebijakan yang telah dikeluarkan oleh Kementerian Kesehatan terkait pelayanan rutin pada balita di Posyandu seperti pemantauan pertumbuhan dan perkembangan balita, imunisasi dasar, pemberian vitamin A dan obat pencegahan cacingan. Namun jika Covid-19 meningkat di suatu daerah maka pelaksanaan pelayanan balita di Posyandu harus ditunda atau dilakukan secara mandiri di rumah (Kemenkes RI, 2020a).

Peran kader sangat penting, terutama di masa pandemi ini dimana gerak sosial dibatasi. Kader tetap berperan aktif dalam mengidentifikasi dan menjawab kebutuhan kesehatan masyarakat. Seperti dalam penelitian ini, kader secara mandiri dapat melaksanakan 
Posyandu dan mengorganisir sasaran dengan baik. Kader berperan aktif dan mampu menjadi pendorong, motivator dan penyuluh di masyarakat .

Dalam kondisi normal sebelum masa pandemi Covid-19, ada beberapa faktor yang mempengaruhi pelaksanaan Posyandu tidak efektif. Faktor-faktor tersebut antara lain karakter kader yang kurang aktif, rendahnya peran lintas sektor dan tokoh masyarakat serta rendahnya keterlibatan ibu dalam pelaksanaan pemantauan pertumbuhan balitanya. Selain itu, tingkat keaktifan kader juga dipengaruhi oleh kesibukan mereka sehari-hari dan juga karena rendahnya insentif yang mereka terima (Ambarita, Husna, \& Sitorus, 2019). Dalam penelitian ini, kader posyandu melaksanakan kegiatan Posyandu atas inisiatif mandiri dan atas dukungan tenaga kesehatan yang pelaksanaannya sesuai dengan kebijakan pemerintah setempat.

Upaya kader dalam melengkapi fasilitas Posyandu tersebut dapat meningkatkan partisipasi ibu membawa balitanya ke Posyandu untuk pemantauan pertumbuhan. Berbagai penelitian menyebutkan bahwa beberapa permasalahan yang membuat partisipasi ibu ke Posyandu rendah yaitu kurangnya fasilitas kesehatan, kurangnya kualitas pelayanan kesehatan di posyandu, dan kurangnya kegiatan dari pihak Puskesmas sehingga bahwa ibu tidak tertarik untuk datang membawa anak ke Posyandu (Lumongga, Sudaryati, \& Theresia, 2020). Namun, keinginan untuk memantau pertubuhan balita menjadi alasan utama ibu mengunjungi Posyandu setiap bulan (Anwar, Khomsan, Sukandar, Riyadi, \& Mudjajanto, 2011; Nazri et al., 2016)

Dalam pelaksanaan Posyandu, petugas kesehatan dan kader Posyandu berupaya melengkapi sarana dan fasilitas yang ada di Posyandu agar sesuai standar protokol kesehatan pencegahan penularan Covid-19 seperti penyediaan tempat cuci tangan, sabun, dan air mengalir, serta tersedianya tempat duduk yang mengatur jarak fisik antar pengunjung. Hal ini menunjukkan komitmen yang tinggi pada kader Posyandu. Komitmen tersebut berimplikasi pada keputusan individu untuk tetap menjalankan tugas dan fungsifungsinya sebagai kader Posyandu meskipun pada masa pandemi Covid-19 (Bidayati, 2017).

Berdasarkan petunjuk tekis pe laksanaan Posyandu di masa pandemi Covid-19 dijelaskan bahwa kader Posyandu bertugas dalam memastikan diri dan kader lainnya dalam keadaan sehat untuk membantu pelayanan di posyandu serta wajib menggunakan alat pelindung diri (APD) yang sesuai dengan prinsip Pencegahan dan Pengendalian Infeksi (PPI) minimal masker kain (Garcia Godoy et al., 2020; Kemenkes RI, 2020b)

Pada penelitian ini, kader Posyandu menggunakan masker sebagai APD standar sesuai dengan prinsip PPI yang telah ditetapkan oleh pemerintah. Kepatuhan penggunaan APD oleh kader Posyandu dipengaruhi oleh beberapa faktor antara lain tingkat pengetahuan dan persepsi kader tentang pentingnya APD yang mempengaruhi praktik penggunaan APD (Nirmalarumsari, 2021). Selain faktor pengetahuan, dukungan dari instansi tempat bekerja berupa penyediaan APD berpengaruh terhadap praktik penggunaan APD (Yanti, Pradiksa, \& Susiladewi, 2021).

Kader juga membantu petugas kesehatan dalam melakukan skrining Covid-19 pada semua pengujung Posyandu dan memastikan ibu dan balitanya duduk di ruang tunggu dengan jarak minimal 1 meter dan mengatur jadwal posyandu agar tidak terjadi penumpukan pengunjung. Hal tersebut telah sesuai dengan aturan pemerintah tentang tugas dan peran kader dalam pelaksanaan Posyandu (Kemenkes RI, 2020b).

Selain itu, beberapa kader melaksanakan Posyandu di ruang terbuka seperti di kolong rumah warga. Hal ini sejalan dengan kebijakan pemerintah bahwa pelayanan kesehatan rutin balita harus dilaksanakan di luar gedung dengan tetap mematuhi prinsip pencegahan penularan Covid-19 yang telah diatur oleh pemerintah setempat. Pada pelaksanaan Posyandu, tenaga kesehatan dan kader Posyandu harus memastikan bahwa semua yang hadir pada kegiatan posyandu seperti ibu dan balitanya, termasuk petugas kesehatan dan kader posyandu itu sendiri harus dalam keadaan sehat dan tidak menunjukkan adanya gejala Covid-19 seperti batuk, pilek, demam dan memastikan suhu tubuh tidak boleh lebih dari $37,5^{\circ} \mathrm{C}$. Semua yang hadir di Posyandu harus menggunakan masker termasuk balita dan harus menjaga jarak pelayanan antara petugas dan sasaran (Kemenkes RI, 2020a).

Untuk pelayanan imunisasi, kader Posyandu dan petugas kesehatan melakukan home visit dengan mengatur waktu kunjungan 
secara bergiliran ke rumah bayi dan baduta yang menjadi sasaran imunisasi. Home visit tersebut dilakukan ketika Posyandu tidak dilaksanakan sesuai jadwal karena adanya kebijakan pemerintah setempat untuk tidak melaksanakan Posyandu sehingga kegiatan pemantauan pertumbuhan dan pelayanan imunisasi pun tertunda. Inisiatif kader tersebut telah sesuai dengan kebijakan pemerintah agar kader dan petugas kesehatan tetap memastikan pemberian imunisasi lengkap kepada balita meskipun di masa pandemi Covid-19 (Kemenkes RI, 2020b). Selain itu, beberapa kader berinisiatif untuk melakukan pemantauan pertumbuhan balita secara mandiri melalui home visit dengan tetap mematuhi protokol kesehatan pencegahan Covid-19.

Pandemi Covid-19 yang terjadi sejak Maret telah berdampak pada penghentian pelayanan Posyandu pada bulan April dan Mei atau bulan-bulan tertentu pada tahun 2020 . Beberapa dampak jangka panjang tidak terlaksananya Posyandu antara lain potensi muncul kejadian luar biasa (KLB) akibat tidak tercapainya cakupan imunisasi nasional dan meningkatnya masalah gizi pada balita terutama stunting (Bappenas RI, 2021). Oleh karena itu peran dan keaktifan kader Posyandu di masa pandemi ini sangat penting untuk tetap memantau pertumbuhan dan perkembangan balita sehingga dapat mengantisipasi risiko meningkatnya kejadian stunting di masa pandemi Covid-19.

\section{KESIMPULAN DAN SARAN}

Para kader telah melaksanakan pelayanan Posyandu sesuai dengan aturan yang telah ditetapkan oleh kementerian Kesehatan dan pemerintah setempat. Kader membuat beberapa inovasi dalam pelaksanaan Posyandu di masa pandemi seperti menyiapkan fasilitas cuci tangan darurat, mengatur jadwal kunjungan dan jarak kursi tunggu di Posyandu, mewajibkan membawa sarung sendiri dari rumah untuk kegiatan penimbangan balita serta melakukan disinfektan ruang Posyandu.

Pemerintah daerah perlu mendukung pelaksanaan Posyandu secara rutin seperti menjamin ketersediaan APD bagi kader posyandu, ibu dan balitanya. Selain itu, setiap Posyandu perlu menyiapkan tempat cuci tangan permanen yang sesuai dengan standar sanitasi yang baik. Hal ini akan mendukung efektivitas pelayanan Posyandu di masa pandemi.
DAFTAR PUSTAKA

Akseer, N., Kandru, G., Keats, E. C., \& Bhutta, Z. A. (2020). Covid-19 pandemic and mitigation strategies: Implications for maternal and child health and nutrition. American Journal of Clinical Nutrition, 112(2), 251-256. https://doi.org/ 10.1093/ajcn/nqaa171.

Ambarita, L. P., Husna, A., \& Sitorus, H. (2019). Pengetahuan kader Posyandu, para ibu balita dan perpektif tenaga kesehatan terkait keaktifan Posyandu di Kabupaten Aceh Barat. Buletin Penelitian Sistem Kesehatan, 22(3), 147157. Retrieved from \%0Apengetahuan kader posyandu, para ibu balita dan perspektif...ejourna12.litbang. kemkes. go.id > hsr > article > download\%0A.

Anwar, F., Khomsan, A., Sukandar, D., Riyadi, H., \& Mudjajanto, E. S. (2011). High participation in the Posyandu nutrition program improved children nutritional status. Nutrition Research and Practice, 4(3), 208. https $/ /$ doi.org/10.4162/ nrp.2010.4.3.208.

Arif, S., Isdijoso, W., Fatah, A. R., \& Tamyis, A. R. (2020). Strategic Review of Food Security and Nutrition in Indonesia.

Bappenas RI. (2021). Studi Pembelajaran Penanganan COVID-19 Indonesia (1st ed.). Jakarta: Bappenas RI.

Bidayati, U. (2017). Commitment, Motivation, and Performance of Posyandu Cadres. Advances in Intelligent Systems Research, 131, 93-97. https://doi.org/ 10.2991/ic oi-17.2017.27.

Creswell, J. W., \& Poth, C. N. (2018). Qualitative Inquiry \& Research Design: Choosing Among Five Approaches. SAGE Publication (5th ed.). California: SAGE Publication. https://doi.org/ 10.13187/rjs.2017.1.30.

Garcia Godoy, L. R., Jones, A. E., Anderson, T. N., Fisher, C. L., Seeley, K. M. L., Beeson, E. A., ... Sullivan, P. D. (2020). Facial protection for healthcare workers during pandemics: A scoping review. BMJ Global Health, 5(5), 1-9. https://doi. org/10.1136/ bmjgh-2020002553.

Kemenkes RI. (2012). Kurikulum dan Modul Pelatihan Kader Posyandu (1st ed.). Jakarta: Kemenkes RI. 
Kemenkes RI. (2020a). Panduan Kesehatan Balita Pada Masa Pandemi Covid-19. Kemenkes RI.

Kemenkes RI. (2020b). Petunjuk Teknis Pelayanan Imunisasi Pada Masa Pandemi Covid-19. Kemenkes RI. Retrieved from https://covid19.kemkes.go.id/ protokolcovid-19/petunjuk- teknis- pelayananimunisasi-pada-masa- pandemi-covid19/\#.X6IYy6ozbIU.

Lumongga, N., Sudaryati, E., \& Theresia, D. (2020). The Relationship of Visits to Posyandu with the Nutrition Status of Toddlers in Amplas Health Center. Budapest International Research and Critics Institute (BIRCI-Journal): Humanities and Social Sciences, 3(3), 2165-2173. https//doi.org/ 10.33258/ birci.v3i3.1149.

Nazri, C., Yamazaki, C., Kameo, S., Herawati, D. M. D., Sekarwana, N., Raksanagara, A., \& Koyama, H. (2016). Factors influencing mother's participation in Posyandu for improving nutritional status of children under-five in Aceh Utara district, Aceh province, Indonesia. BMC Public Health, 16(1), 1-9. https://doi.org/ 10.1186/s12889-016-2732-7.

Nicola, M., Alsafi, Z., Sohrabi, C., Kerwan, A., Al-Jabir, A., Iosifidis, C., ... Agha, R. (2020). The socio-economic implications of the coronavirus pandemic (COVID19): A review. International Journal of Surgery, 78(January), 185-193. https://doi.org/10.1016/j.ijsu.2020.04.018

Nirmalarumsari, C. (2021). Hubungan tingkat pengetahuan, sikap, kedisiplinan perawat dengan penggunaan APD di masa pandemi Covid-19 di Puskesmas Wara Selatan Kota Palopo. Jurnal Kesehatan Luwu Raya, 8(1), 21-30.
Qian, M., \& Jiang, J. (2020). Covid-19 and Social Distancing. Journal of Public Health, (Mikulska 2019). https://doi.org/ 10.1007/s10389-020-01321-z.

Rahmawati, N. D., \& Dewi Sartika, R. A. (2020). Cadres' role in Posyandu revitalization as stunting early detection in Babakan Madang Sub-District, Bogor District. ASEAN Journal of Community Engagement, 4(2), 485-499. https://doi.org/10.7454/ajce.v4i2.1055.

Rinayati, Erawati, A. D., \& Wahyuning, S. (2020). Gambaran tingkat pengetahuan dan kinerja kader kesehatan. Jurnal Ilmiah Permas: Jurnal Ilmiah STIKES Kendal, 10(3), 359-364.

Sari, N., Chiani, S. H., \& Astuti, W. (2020). Tingkat Pengetahuan Kader Tentang Kegiatan Posyandu Di Posyandu Beringin Jaya Dusun Poto Tahun 2019. Jurnal Kesehatan Dan Sains, 3 (2)(2), 19.

WHO. (2020). Covid-19: Physical Distancing. Retrieved from Physical distancing helps limit the spread of COVID-19 - this means we keep a distance of at least $1 \mathrm{~m}$ from each other and avoid spending time in crowded places or in groups.

World Food Programme. (2020). Covid-19: Economic and Food Security Implications. Retrieved from https://docs.wfp.org/api/documents/WFP $-0000116063 /$ download/?_ga=2. 119036809.1075483963. 6030947781862813034.1603094778.

Yanti, N. P. E. D., Pradiksa, H., \& Susiladewi, I. A. M. V. (2021). Gambaran pengetahuan perawat tentang APD dan kebersihan tangan di Masa Pandemi Coronavirus Disease 2019. Jurnal Keperawatan, 13(1), 213-226. 